\title{
PENERAPAN MEDIA VIDEO BENCANA ALAM DALAM MENINGKATKAN KETERAMPILAN MENULIS PUISI LAMA (SYAIR)
}

\author{
IMPLEMENTATION OF NATURAL DISASTER VIDEO MEDIA IN IMPROVING \\ THE SKILL OF WRITING OLD POETS (SYAIR)
}

\author{
Nurjayanti \\ Kaharuddin ${ }^{1}$ \\ Universitas \\ Sawerigading \\ Makassar $^{1}$ \\ email: \\ nurjayantikaaruddin 88 \\ @gmail.com \\ Isnani Arianti ${ }^{2}$ \\ Universitas \\ Sawerigading \\ Makassar $^{2}$ \\ email: \\ firas.rabbi14@gmail.co \\ m \\ IJI Publication \\ p-ISSN: 2774-1907 \\ e-ISSN: 2774-1915 \\ Vol.1, No.1, pp.53-60, \\ Nopember 2020

\footnotetext{
Unit Publikasi Ilmiah Intelektual Madani Indonesia
}

Abstrak: Penelitian ini menggunakan pendekatan kualitatif dan jenis penelitian digolongkan ke dalam Penelitian Tindakan Kelas (Classroom Action Research). Penelitian tindakan ini dilakukan untuk mendeskripsikan dan mengamati proses belajar siswa dengan menggunakan media video bencana alam. Tahap pertama menyusun rancangan tindakan, tahap kedua pelaksanaan tindakan, tahap ketiga pengamatan, dan terakhir tahap refleksi. Hasil penelitian penanganan dalam masalah pembelajaran di kelas dengan penggunaan media video bencana alam menjadi solusi yang preventif, dalam hal ini kesulitan siswa menuangkan ide atau gagasannya dan untuk meningkatkan hasil belajar siswa dalam menulis puisi lama (syair). Hal ini terlihat dari hasil pencapaian skor rata-rata siswa yang mengalami peningkatan, yaitu dari skor $66,52 \%$ menjadi $82,17 \%$. Peneliti menyampaikan saran sebagai berikut: (1) Guru diharapkan untuk senantiasa membimbing dan memotivasi siswa dalam pencapaian hasil belajar yang lebih baik. (2) Diharapkan kepada guru untuk menggunakan strategi pembelajaran puisi lama (syair) dengan menggunakan media video bencana alam sebagai variasi dalam mengajarkan materi menulis puisi lama (syair).

Kata Kunci: Media Video; Bencana Alam; Menulis Puisi; Syair.

Abstract: His study uses a qualitative approach and the type of research is classified into Classroom Action Research. This action research was conducted to describe and observe the student learning process using natural disaster video media. The first stage is compiling an action plan, the second stage is implementing the action, the third stage is observation, and the last stage is reflection. The results of research on the handling of learning problems in the classroom using video media of natural disasters are a preventive solution, in this case the difficulty of students expressing their ideas or ideas and to improve student learning outcomes in writing old poetry (syair). This can be seen from the results of the achievement of the student's average score which has increased, namely from a score of $66.52 \%$ to $82.17 \%$. Researchers convey the following suggestions: (1) Teachers are expected to always guide and motivate students in achieving better learning outcomes. (2) It is hoped that teachers will use old poetry learning strategies using natural disaster video media as variations in teaching material for writing old poetry (syair).

Keywords: Media Video; Natural Disasters; Writing Poetry; Poetry.

\section{PENDAHULUAN}

Pembelajaran bahasa Indonesia memuat empat aspek kompetensi yang harus dikuasai. Keempat aspek tersebut adalah kompetensi membaca, menyimak atau mendengarkan, berbicara, dan menulis. Pembelajaran bahasa diharapkan dapat membantu peserta didik mengenal dirinya, kebudayaan-kebudayaan yang ada, mengungkapkan gagasan atau ide dan perasaannya, dan menemukan serta mengembangkan kompetensi analitis dan imajinasi yang dimilikinya. Selain itu, pembelajaran bahasa Indonesia sebagai salah satu mata pelajaran umum di sekolah diarahkan untuk meningkatkan kemampuan peserta didik dalam berkomunikasi dengan menggunakan bahasa Indonesia yang baik dan benar, baik secara lisan maupun tertulis, serta menumbuhkan apresiasi terhadap hasil karya sastra Indonesia.

Keberadaan karya-karya sastra apabila dianggap tidak memberikan manfaat, tidak berguna lagi dalam menafsirkan dan memberikan pemahaman pada masalahmasalah dunia nyata maka pengajaran karya sastra tidak perlu lagi diadakan. Akan tetapi jika relevansi karya sastra dengan dunia nyata dapat ditunjukkan, pengajaran karya sastra harus dipandang sebagai sesuatu yang sangat penting dan mendapatkan ruang yang tepat dan layak pada proses pembelajaran. Penggunaan metode pengajaran yang tepat menjadikan pengajaran sastra tidak bisa dipandang sebelah mata dan dapat memberikan sumbangan besar dalam 
penyelesaian masalah-masalah nyata yang dianggap sulit dalam lingkungan masyarakat.

Sastra pada hakikatnya merupakan salah satu peristiwa budaya bangsa yang dilambangkan melalui bahasa. Tanpa bahasa, sastra tidak mungkin mewujudkan dirinya, baik dalam bentuk lisan maupun tulisan. Peran bahasa dalam karya sastra merupakan alat pembentuk iluminasi, imajinasi, dan daya pikir yang dapat membangkitkan pikiran dan merangsang intuisi seseorang dalam menyampaikan amanat. Seni yang menggunakan bahasa tentunya memiliki karakteristik sendiri yang berbeda dengan seni lainnya. Artinya, pembelajaran sastra dengan sendirinya akan turut mempertinggi kemampuan berbahasa.

Proses pembelajaran puisi dapat dilakukan dengan berbagai strategi. Namun, kenyataan di lapangan seringkali hasil proses pembelajaran tidak sesuai dengan harapan. Proses pembelajaran masih banyak menghadapi kendala, di antaranya pelaksanaan Kurikulum Tingkat Satuan Pendidikan (KTSP) pada mata pelajaran bahasa dan sastra Indonesia khususnya puisi masih dijumpai proses pembelajaran yang belum optimal. Banyak siswa yang mengeluh terhadap materi puisi. Sebagian siswa menganggap materinya sulit. Sebagiannya lagi menganggap pelajaran puisi bukan pelajaran yang menyenangkan karena selain menguras otak untuk berpikir, penerapannya juga membutuhkan mental percaya diri yang tinggi.

Dengan adanya kondisi di lapangan yang terdapat kendala pada proses pembelajaran puisi, peneliti ingin mengubah paradigma siswa dengan mengoptimalkan pembelajaran puisi melalui strategi pembelajaran puisi model sinektik. Melalui penelitian ini, peneliti berharap siswa mampu memahami sepenuhnya pembelajaran puisi, lebih aktif dalam proses pembelajaran, dan paradigma siswa berubah menjadi puisi adalah mata pelajaran yang menyenangkan.

Fenomena yang terjadi dalam dunia pendidikan adalah kurangnya minat siswa dalam mata pelajaran bahasa Indonesia, kurang kreatifnya guru dalam melakukan pengelolaan kelas dan memilih metode yang tepat, sarana dan prasarana yang tidak menunjang, serta kurangnya kompetensi siswa dalam memahami materi pembelajaran, khususnya pemahaman kesusastraan. Ini merupakan masalah yang kerap ditemukan dalam proses pembelajaran bahasa Indonesia yang harus mendapatkan solusi tepat dalam penanganannya. Oleh karena itu, tujuan penelitian ini adalah untuk mengetahui dan menganalisis penerapan media video bencana alam dalam meningkatkan proses dan hasil menulis puisi lama (Syair) siswa kelas VIII MTs Al-Hidayah Makassar.

\section{METODE}

Penelitian ini menggunakan pendekatan kualitatif dan jenis penelitian digolongkan ke dalam Penelitian Tindakan Kelas (Classroom Action Research). Penelitian tindakan ini dilakukan untuk mendeskripsikan dan mengamati proses belajar siswa dengan menggunakan media video bencana alam. Tahap pertama menyusun rancangan tindakan, tahap kedua pelaksanaan tindakan, tahap ketiga pengamatan, dan terakhir tahap refleksi. Data penelitian ini berupa data perencanaan, pelaksanaan, evaluasi, dan hasil penelitian. Data penelitian diperoleh melalui hasil observasi sebelum penelitian dilakukan dan ditambah dengan studi dokumentasi hasil tes pada setiap tindakan hasil refleksi dari penggunaan media video bencana alam sebagai media pembelajaran dalam menulis puisi lama (Syair) siswa MTs Al-Hidayah Makassar, sedangkan sumber data berupa data lisan dan tertulis merupakan data penelitian yang diperoleh dari sumber data (guru dan siswa). Data lisan diperoleh dari informan kunci (key informant) dalam hal ini 
guru yang mengetahui tentang cara kerja siswa dan siswa sendiri serta data tertulis diperoleh dari hasil kerja siswa menulis puisi yang terteliti, yaitu berjumlah 17 orang. Teknik pengumpulan data yang digunakan dalam penelitian ini adalah teknik dokumentasi, teknik observasi, dan teknik analisis teks (latihan atau penugasan). Data hasil penelitian di analisis dengan tahapan pengelompokan data, reduksi data, penyajian data, penarikan kesimpulan. Data yang telah diolah kemudian diuji dengan teknik triangulasi atau pengujian hasil temuan penelitian.

\section{HASIL DAN DISKUSI}

\section{Penggunaan Media Video Bencana Alam dalam Pembelajaran Menulis Puisi Lama (syair)}

Penggunaan media video bencana alam sebagai solusi dalam permasalahan pembelajaran di kelas sebagai upaya peningkatan kemampuan siswa menulis puisi. Pada dasarnya, siswa memiliki keinginan menyampaikan gagasannya dalam bentuk puisi. Namun yang terjadi di lapangan, siswa kesulitan menuangkan ide atau gagasan dalam bentuk puisi. Permasalahan ini menjadi tantangan bagi guru untuk mengambil langkah solutif sebagai pihak yang berinteraksi langsung dengan siswa. Dengan demikian, penggunaan media video bencana alam menjadi solusi yang preventif.

Berdasar pada perencanaan, upaya penanganan permasalahan pembelajaran menulis puisi dilakukan dalam bentuk tindakan dengan menggunakan sistem siklus atau lebih dikenal dengan Penelitian Tindakan Kelas (Arikunto, 2009:16). Penelitian ini dilakukan dua siklus, pada tiap siklus terbagi ke dalam empat tahap.

1) Proses penggunaan Media Video Bencana Alam dalam Pembelajaran Menulis Puisi Lama (Syair) Siklus I

a) Tahap Perencanaan
Berdasarkan hasil perencanaan awal yang dilakukan oleh guru mata pelajaran bahasa Indonesia dengan peneliti, tahap perencanaan dilakukan dengan mendiskusikan tindakan yang akan dilakukan pada proses pembelajaran yang akan berlangsung. Media video bencana alam akan digunakan sebagai media pembelajaran untuk memudahkan dan merangsang siswa menuangkan idenya dalam bentuk puisi. Kemudian bahan pembelajaran atau materi pembelajaran digunakan buku teks siswa kelas VIII sesuai dengan Rancangan Pelaksanaan Pembelajaran (RPP) yang disusun bersama. Guru dilatih menggunakan media video bencana alam yang telah disiapkan oleh peneliti. Kegiatan ini dilakukan sehingga guru benar-benar siap pada proses pembelajaran di kelas.

b) Tahap Tindakan dan Pengamatan Guru melakukan tindakan (pembelajaran) sesuai hasil perencanaan yang dilakukan bersama dengan peneliti. Guru melakukan kegiatan awal, kemudian membahas materi tentang menulis puisi lama (syair), menampilkan media video bencana alam, selanjutnya siswa diberi penugasan, dan terakhir guru menutup kegiatan pembelajaran.

Kegiatan awal dilakukan oleh guru untuk memulai proses pembelajaran. Guru melakukan pengelolaan kelas dan memperkenalkan materi pembelajaran yang akan dilaksanakan. Selanjutnya guru melakukan apersepsi dengan memberikan pertanyaan kepada siswa tentang menulis puisi.

Memasuki kegiatan inti, guru memaparkan materi pembelajaran tentang pengertian puisi dan menuangkan gagasan atau ide dalam bentuk puisi dengan berpedoman pada buku teks yang telah disiapkan. Selanjutnya, siswa menyaksikan video bencana alam yang ditampilkan. Video yang ditampilkan sebanyak 3 buah dengan durasi yang berbeda-beda dan dengan waktu 
yang singkat. Setelah pemutaran video selesai, siswa ditugaskan menulis puisi bebas dengan tema bencana alam. Selanjutnya, hasil menulis puisi siswa dikumpulkan.

Kegiatan terakhir, guru dan siswa merangkum materi pembelajaran menulis puisi. Dilanjutkan dengan guru dan siswa melakukan refleksi terhadap kegiatan pembelajaran yang telah dilakukan. Kemudian guru menutup kegiatan pembelajaran. Kegiatan pembelajaran pun berakhir. Dengan demikian, kegiatan pada siklus I berakhir.

Ketika pembelajaran berlangsung, peneliti mengamati proses pembelajaran dengan cermat. Peneliti mencatat hal-hal yang terjadi pada proses pembelajaran dengan menggunakan lembar catatan lapangan yang telah disiapkan sebelumnya. Peneliti mengamati aktivitas guru dan siswa selama kegiatan pembelajaran berlangsung dengan cermat.

Secara jelas, hasil pengamatan peneliti disajikan dalam tabel berikut:

Tabel 1

Aktivitas Siswa pada Siklus I

\begin{tabular}{|c|c|c|c|c|}
\hline \multirow[b]{2}{*}{ No } & \multirow[b]{2}{*}{ Kegiatan Pembelajaran } & \multicolumn{3}{|c|}{ Penilaian } \\
\hline & & Aktif & $\begin{array}{l}\text { Kurang } \\
\text { Aktif }\end{array}$ & $\begin{array}{l}\text { Tidak } \\
\text { Aktif }\end{array}$ \\
\hline 1 & $\begin{array}{l}\text { Siswa menyimak tujuan } \\
\text { pembelajaran yang } \\
\text { disampaikan oleh guru. }\end{array}$ & & & $\sqrt{ }$ \\
\hline 2 & $\begin{array}{l}\text { Siswa menyimak materi } \\
\text { pembelajaran. }\end{array}$ & & $\sqrt{ }$ & \\
\hline 3 & $\begin{array}{l}\text { Siswa menyaksikan video } \\
\text { bencana alam yang } \\
\text { ditampilkan dengan } \\
\text { menggunakan LCD }\end{array}$ & $\sqrt{ }$ & & \\
\hline 4 & $\begin{array}{l}\text { Siswa menulis puisi } \\
\text { berdasarkan petunjuk } \\
\text { yang diberikan oleh guru. }\end{array}$ & & $\sqrt{ }$ & \\
\hline 5 & $\begin{array}{l}\text { Siswa menyimpulkan } \\
\text { materi pembelajaran. }\end{array}$ & & & $\sqrt{ }$ \\
\hline
\end{tabular}

Sumber: Survei Maret 2015

c) Tahap Refleksi

Kekurangan atau masalah pada pelaksanaan siklus I dirumuskan dan diidentifikasi berdasarkan pengamatan yang dilakukan peneliti saat proses pembelajaran berlangsung pada tahap ini. Kegiatan ini dilakukan bersama oleh guru dan peneliti.
Secara cermat, kegiatan pada siklus I ditelaah bersama.

Berdasarkan hasil telaah yang dilakukan, siklus I disimpulkan belum berhasil. Banyak faktor yang menyebabkan ketidakberhasilan pada siklus I. Mulai dari kegiatan awal pembelajaran sampai kegiatan menutup pembelajaran, siswa terlihat acuh ketika proses pembelajaran berlangsung. Pada kegiatan awal pembelajaran, guru tidak menjelaskan tujuan pembelajaran secara jelas. Urutan kegiatan awal kurang sesuai dengan RPP yang telah dibuat. Hal ini menyebabkan siswa tidak aktif pada kegiatan awal pembelajaran.

Memasuki kegiatan inti, umumnya siswa kurang aktif dalam menyimak materi pembelajaran sehingga kegiatan pada tahap ini siswa tampak acuh mengikuti proses pembelajaran. Memasuki tahap selanjutnya pada penggunaan media video bencana alam semua siswa aktif. Tampak antusiasme menyaksikan video yang ditampilkan sehingga proses pembelajaran kembali terarah. Video yang ditampilkan hanya 1 buah saja dengan durasi yang panjang. Terakhir, pada tahap ini siswa diberi postes oleh guru dengan menulis puisi bebas tema bencana alam. Siswa menulis puisi sambil mendengarkan guru memberikan petunjuk atau arahan dalam menulis puisi, selanjutnya hasil kerja siswa dikumpulkan.

Kegiatan akhir, siswa tidak aktif dalam kegiatan menyimpulkan materi pembelajaran sehingga guru yang memberikan kesimpulan terhadap materi pembelajaran. Terakhir, proses pembelajaran ditutup dengan membaca doa.

Setelah siswa mengikuti proses pembelajaran, peneliti melakukan wawancara bebas terpimpin dengan siswa. Dari hasil wawancara yang dilakukan, secara umum siswa sering menulis puisi. Masalah yang dialami ketika menulis puisi terletak pada kesulitan memilih kata yang tepat atau diksi yang sesuai. Selain itu, siswa juga mengalami 
kesulitan memahami materi pembelajaran yang disebabkan karena cara penyampaian materi yang kurang menarik. Sehingga ini berdampak pada hasil kerja siswa menulis puisi tidak maksimal.

Berdasarkan hasil evaluasi terhadap teks puisi yang ditulis siswa, upaya peningkatan kemampuan menulis puisi siswa belum sesuai dengan tujuan pelaksanaan PTK. Berpedoman pada pendapat Nurgiantoro (2009) bahwa proses pembelajaran guru dapat dikatakan efektif apabila siswa mendapatkan nilai $65 \%$ sampai $100 \%$ atau dalam kategori sedang, tinggi, dan sangat tinggi. Terbukti pada siklus ini tidak sesuai dengan tujuan penelitian sehingga disimpulkan bahwa siklus I tidak berhasil dan harus dilanjutkan pada siklus berikutnya atau siklus II sebagai upaya pencapaian tujuan penelitian yang dilakukan.

2) Proses penggunaan Media Video Bencana Alam dalam Pembelajaran Menulis Puisi Lama (Syair) Siklus II

a) Tahap Perencanaan

Disebabkan karena siklus I belum berhasil, maka siklus II mutlak dilaksanankan. Langkah selanjutnya dalam PTK ini adalah merancang kembali tindakan yang akan dilakukan pada siklus II. RPP kembali disusun secara rinci, menyiapkan media pembelajaran video bencana alam untuk digunakan pada siklus ini, menyiapkan bahan dan materi pembelajaran, dan guru kembali berlatih untuk melaksanakan proses pembelajaran. Semua ini dilakukan oleh guru dan peneliti secara berkolaborasi.

b) Tahap Tidakan dan Pengamatan

Tahap tindakan dan pengamatan dilaksanakan di kelas secara bersama-sama oleh peneliti dan guru. Peneliti tetap bertindak sebagai pengamat yang bertugas mengamati tidakan yang dilakukan oleh guru dan siswa selama proses pembelajaran berlangsung.

Sesuai dengan perencanaan untuk siklus II, kegiatan awal guru melakukan pengelolaan kelas dan meminta siswa membaca doa. Selanjutnya, siswa diberi penjelasan tujuan pembelajaran menulis puisi bebas dengan jelas. Kemudian, siswa diberikan pretes. Pemahaman awal siswa tentang menulis puisi kembali ditinjau. Tahap ini, perhatian siswa terkontrol pada proses pembelajaran yang sedang berlangsung sehingga pada kegiatan awal siswa tampak aktif mengikuti kegiatan pembelajaran.

Memasuki kegiatan inti, guru memaparkan teori atau materi pembelajaran mengenai menulis puisi lama (syair). Berbeda dengan pemaparan materi pembelajaran pada siklus I, kali ini materi pembelajaran diajarkan lebih ringan sehingga siswa mudah memahami apa yang disampaikan. Guru berupaya memberikan motivasi dengan menceritakan keberhasilan tokoh-tokoh yang terkenal dengan menulis. Tahap selanjutnya, siswa menyaksikan pemutaran video bencana alam. Setelah menyaksikan video bencana alam, guru memberikan arahan dan petunjuk penulisan puisi lama (syair). Kemudian siswa melakukan postes dengan menulis puisi bebas bertema bencana alam. Terakhir, siswa mengumpulkan hasil menulis puisi. Pada kegiatan ini, siswa terlihat antusias dan bersemangat mengerjakan tugas menulis puisi lama (syair) yang diberikan oleh guru.

Kegiatan akhir, siswa mengungkapkan kesulitan yang dialami dalam menulis puisi lama (syair). Dalam kegiatan ini, siswa tampak aktif mengungkapkan kesulitan dalam menulis puisi tanpa segan. Setelah itu, guru dan siswa bersama-sama merangkum materi pembelajaran menulis puisi. Terakhir, proses pembelajaran ditutup dengan membaca doa.

Secara umum proses pada siklus II siswa tampak aktif. Hal ini berdasarkan pada pengamatan yang dilakukan oleh peneliti. Antusias dan minat siswa menulis puisi pun lebih terlihat jika dibandingkan dengan respon siswa mengikuti proses pembelajaran pada siklus I. Secara jelas, berikut ini disajikan tabel aktivitas siswa pada siklus II: 


\begin{tabular}{|c|c|c|c|c|}
\hline \multirow[b]{3}{*}{ No } & \multicolumn{4}{|c|}{$\begin{array}{c}\text { Tabel } 2 \\
\text { Aktivitas Siswa pada Siklus II }\end{array}$} \\
\hline & & & Penilaian & \\
\hline & Kegiatan Pembelajaran & Aktif & $\begin{array}{l}\text { Kurang } \\
\text { Aktif }\end{array}$ & $\begin{array}{l}\text { Tidak } \\
\text { Aktif }\end{array}$ \\
\hline 1 & $\begin{array}{l}\text { Siswa menyimak tujuan } \\
\text { pembelajaran yang } \\
\text { disampaikan oleh guru. }\end{array}$ & $\sqrt{ }$ & & \\
\hline 2 & $\begin{array}{l}\text { Siswa menyimak materi } \\
\text { pembelajaran. }\end{array}$ & $\sqrt{ }$ & & \\
\hline 3 & $\begin{array}{l}\text { Siswa menyaksikan video } \\
\text { bencana alam yang } \\
\text { ditampilkan dengan } \\
\text { menggunakan LCD }\end{array}$ & $\sqrt{ }$ & & \\
\hline 4 & $\begin{array}{l}\text { Siswa menulis puisi } \\
\text { berdasarkan petunjuk } \\
\text { yang diberikan oleh guru. }\end{array}$ & $\sqrt{ }$ & & \\
\hline 5 & $\begin{array}{l}\text { Siswa menyimpulkan } \\
\text { materi pembelajaran. }\end{array}$ & & $\sqrt{ }$ & \\
\hline
\end{tabular}

Sumber: Survei Agustus 2010

Berdasarkan pengamatan ini, tampak ada kemajuan dalam kegiatan pembelajaran. Secara umum, siswa tampak aktif mengikuti kegitan pembelajaran dari kegiatan awal sampai kegiatan akhir atau sempai proses pembelajaran ditutup. Dengan demikian, proses pembelajaran menulis puisi lama (syair) dapat dikatakan berhasil dengan maksimal.

c) Tahap Refleksi

Evaluasi siklus II dilakukan pada tahap refleksi. Peneliti dan guru mengidentifikasi masalah atau kesulitan pada siklus II. Kegiatan refleksi dilakukan untuk meninjau kembali proses pelaksanaan pembelajaran pada siklus II. Setelah peneliti dan guru menelaah secara cermat, siklus II dapat dikatakan berhasil berdasarkan hasil analisis pelaksanaan kegiatan dan hasil analisis teks puisi siswa dan penilaian proses yang dilakukan.

\section{Hasil Tes Kemampuan Siswa Menulis Puisi Lama (Syair)}

Hasil kolaborasi antara peneliti dan guru pada saat perancangan RPP, aspek yang dinilai pada teks puisi siswa mencakup 5 aspek, yaitu (1) pemilihan judul, (2) pemanfaatan gaya bahasa, (3) penggunaan diksi, (4) amanat yang terkandung dalam puisi, dan (5) kreativitas siswa. Skor tertinggi untuk aspek pertama sebanyak 9 poin, aspek kedua 15 poin, aspek ketiga 30 poin, aspek keempat 20 poin, dan aspek yang kelima sebanyak 15 poin. Jadi skor maksimal yang bisa dikumpulkan oleh siswa sebanyak 89 poin. Deskripsi peningkatan hasil tes kelima aspek dalam menulis puisi secara jelas dipaparkan berikut ini:

1) Aspek Pemilihan Judul

Rata-rata perolehan skor untuk penilaian aspek pertama (pemilihan judul) pada siklus I hanya mencapai 6.76 poin dengan skor maksimal 9 poin. Dari hasil pemeriksaan yang dilakukan, pada siklus ini siswa kurang mempertimbangkan unsur keindahan dalam menentukan judul puisi. Judul puisi kurang mencerminkan seluruh isi, selain itu banyak judul puisi siswa yang bertele-tele. Hal ini mengurangi perolehan skor pada aspek pertama.

Berbeda pada siklus I, siklus II menunjukkan peningkatan yang signifikan dengan upaya perbaikan yang dilakukan. Secara umum, penentuan judul puisi yang dilakukan oleh siswa mulai mencerminkan isi, aspek keindahan tidak lagi diabaikan, dan secara umum pemilihan kata pada judul padat. Sehingga skor rata-rata pada siklus II mencapai 8.23 dari skor maksimal 9 poin.

2) Aspek Penggunaan Gaya Bahasa

Penggunaan gaya bahasa dalam puisi siswa sangat kurang. Pada siklus I, secara umum siswa seperti menulis paragraf dekripsi bukan menulis puisi lama (syair). Gaya bahasa yang digunakan kurang menarik, bahkan terkesan membosankan. Penggunaan gaya bahasa yang dapat meningkatkan efek bagi pembacanya diabaikan. Skor rata-rata yang diperoleh siswa hanya sebanyak 10.79 poin dari skor maksimal sebanyak 15 poin.

Perolehan skor rata-rata pada siklus II meningkat menjadi 13.14 poin. Hal ini karena gaya bahasa dalam puisi siswa sudah mulai mehidupkan efek pada pembacanya. Meskipun belum maksimal, gaya bahasa mulai digunakan. Gaya bahasa yang dipilih sesuai dengan suasana yang ingin diciptakan. 
3) Aspek Penggunaan Diksi

Tidak jauh berbeda dengan aspek pertama dan kedua, pada siklus I aspek penggunaan diksi juga kurang memerhatikan unsur keindahan. Pilihan kata dan susunannya biasa-biasa saja. Hal ini menyebabkan perolehan skor rata-rata juga sangat rendah, hanya mencapai 20 poin dari skor maksimal 30 poin.

Tampak peningkatan yang baik dalam penggunaan diksi pada siklus II. Pilihan katanya sudah menampakkan keindahan. Susunannya pun mulai tampak cermat. Walaupun tidak menunjukkan hasil yang maksimal, diksi yang digunakan siswa mudah dipahami. Perolehan skor rata-rata meningkat pada siklus II menjadi 23.29 poin.

4) Aspek Amanat

Secara umum, puisi yang ditulis siswa pada tiap siklus mengandung amanat yang ingin disampaikan kepada pembaca. Namun pada siklus I, maksud dan tujuan yang ingin disampaikan kurang dimengerti. Skor ratarata yang diperoleh pada siklus I hanya mencapai 13.85 poin. Berbeda pada siklus II, amanat yang dikandung dalam puisi siswa dapat ditelaah. Selain itu, maksud dan tujuannya sesuai dengan tema. Hal ini memberikan peningkatan perolehan skor ratarata menjadi 16.73 poin dari skor maksimal 20 poin.

5) Aspek Kreativitas Siswa

Mengamati keempat aspek yang menjadi kriteria penilaian pada puisi siswa, aspek kelima yang dinilai yaitu kreativitas siswa. Peningkatan hasil penilaian dari siklus I dan siklus II juga tampak pada aspek ini. Perolehan skor rata-rata dari 9.5 poin menjadi 12.32 poin dengan skor maksimal 15 poin. Hal ini menunjukkan peningkatan sesuai dengan tujuan yang ingin dicapai.

Perolehan skor tiap aspek pada siklus I dan II diperbandingkan dalam diagram batang di bawah ini :
Gambar 1

Peningkatan Perolehan Skor Tiap Item Penilaian pada Tiap Siklus dalam Menulis Puisi Lama (Syair)

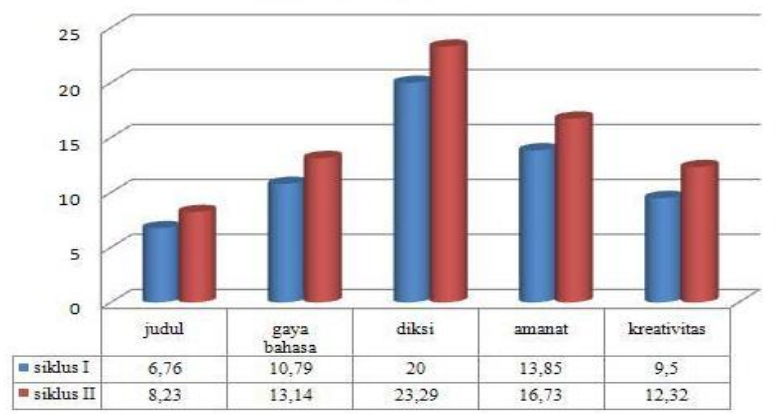

Diagram di atas menunjukkan dengan jelas pencapaian skor rata-rata pada setiap aspek yang dinilai dalam menulis puisi oleh siswa dengan tema bencana alam. Mulai dari aspek pemilihan judul, penggunaan gaya bahasa, penggunaan diksi, amanat yang terkandung, dan kreativitas siswa pada siklus I mengalami peningkatan pada siklus II. Sedangkan perolehan skor rata-rata nilai akhir digambarkan pada diagram di bawah ini :

Gambar 2

Peningkatan Perolehan Skor Rata-rata Tiap Siklus dalam Menulis Puisi Lama (Syair)

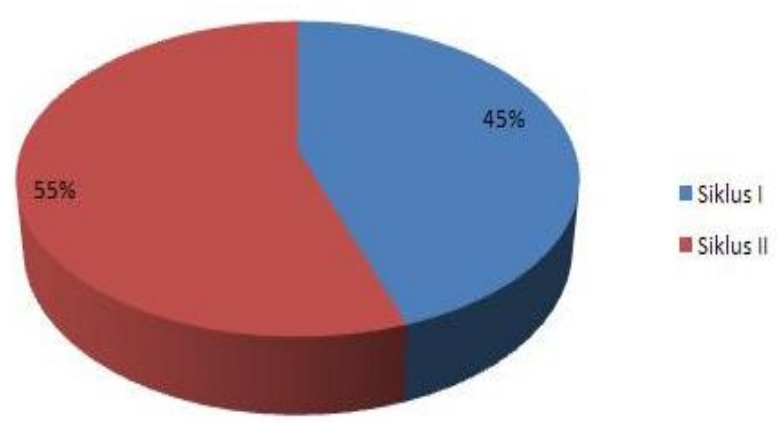

Hasil akumulasi analisis teks puisi lama (syair) siswa siklus I dan II menunjukkan hasil yang maksimal. Hal ini terlihat dari siklus I nilai akhir perolehan siswa yang ratarata hanya bisa memeroleh $66,52 \%$ mengalami penigkatan menjadi $82,17 \%$. Secara individu, semua telah mencapai taraf keberhasilan, yaitu nilai dalam kategori sedang, tinggi, dan sangat tinggi atau mendapatkan nilai 65\% ke atas (Nurgiantoro, 2009). 
Upaya penanganan dalam masalah pembelajaran di kelas, dalam hal ini kesulitan siswa menuangkan ide atau gagasan dalam bentuk puisi dengan menggunakan media video bencana alam sangat tepat. Dengan demikian, penggunaan media video bencana alam dalam proses pembelajaran menulis puisi lama (syair) siswa kelas VIII berhasil efektif

\section{KESIMPULAN}

Setelah melakukan penelitian tindakan kelas VIII di MTs Al-Hidayah Makassar sebagaimana perumusan masalah yang telah diajukan di bagian pendahuluan, maka peneliti menyimpulkan; 1) penggunaan media video bencana alam dalam proses menulis puisi lama (syair) siswa kelas VIII di MTs AlHidayah Makassar mengalami peningkatan. 2) penggunaan media video bencana alam dalam menulis puisi lama (syair) siswa kelas VIII di MTs Al-Hidayah Makassar dapat meningkatkan hasil menulis puisi siswa. 3) Upaya penanganan dalam masalah pembelajaran di kelas dengan penggunaan media video bencana alam menjadi solusi yang preventif, dalam hal ini kesulitan siswa menuangkan ide atau gagasannya dan untuk meningkatkan hasil belajar siswa dalam menulis puisi lama (syair). Hal ini terlihat dari hasil pencapaian skor rata-rata siswa yang mengalami peningkatan, yaitu dari skor $66,52 \%$ menjadi $82,17 \%$.

\section{REFERENSI}

A.S, Sutjarso. 2005. "Sejarah Sastra Indonesia". Makassar: UNM.

\section{6. "Pengajaran Puisi} Indonesia". Makassar: UNM.

Depdikbud. 1990. Kamus Besar Bahasa Indonesia. Jakarta: Balai Pustaka.

Depdiknas. 2006. KTSP Mata Pelajaran Bahasa Indonesia. Jakarta: Depdiknas.

Djuanda. 2006. "Pengkajian Prosa dan Fiksi Indonesia". Makassar: UNM.
Djumingin, Sulastriningsih. 2007. "Pengajaran

Prosa Fiksi dan Drama Indonesia". Makassar: UNM.

Enre, Fachruddin Ambo. 1994. "Pembinaan Generasi Penerud Melalui Kegiatan Sastra." Makalah, Ujung Pandang: Seminar Himpunan Pembinaan dan Pengembangan Bahasa Indonesia. 